\title{
Valorization of Kimberlite Tailings by Carbon Capture and Utilization (CCU) Method
}

\author{
Cibi Chakravarthy, Salma Chalouati, Ye Eun Chai $\odot$, Hugo Fantucci $\odot$ and Rafael M. Santos \\ School of Engineering, University of Guelph, 50 Stone Rd. E, Guelph, ON N1G 2W1, Canada; \\ cibichakravarthy@hotmail.com (C.C.); chalouatis@gmail.com (S.C.); ychai@uoguelph.ca (Y.E.C.); \\ hfantucc@uoguelph.ca (H.F.) \\ * Correspondence: santosr@uoguelph.ca
}

Received: 5 June 2020; Accepted: 6 July 2020; Published: 8 July 2020

\begin{abstract}
In the world of construction, cement plays a vital role, but despite its reputation and affordable prices, the cement industry faces multiple challenges due to pollution and sustainability concerns. This study aimed to assess the possibility of utilizing carbonated kimberlite tailings, a waste product from diamond mining, as a partial cement substitute in the preparation of concrete bricks. This is a unique opportunity to help close the gap between fundamental research in mineral carbonation and its industrial implementation to generate commercial products. Kimberlite was subjected to a mild thin-film carbonation process in a $\mathrm{CO}_{2}$ incubator at varying levels of $\mathrm{CO}_{2}$ concentration ( $10 \mathrm{vol} \%$ and $20 \mathrm{vol} \%$ at ambient pressure), kimberlite paste moisture content $(10 \mathrm{wt} \%$ to $20 \mathrm{wt} \%)$, and chamber temperature $\left(35\right.$ and $\left.50{ }^{\circ} \mathrm{C}\right)$. The formation of magnesium carbonates, in the form of nesquehonite and lansfordite, was verified by X-ray diffraction analysis, and total $\mathrm{CO}_{2}$ uptake was quantified by thermal decomposition in furnace testing. Carbonated kimberlite tailings were then used to cast bricks. Replacement of cement between $10 \%$ and $20 \%$ were tested, with a constant water-to-binder ratio of $0.6: 1$, and a cementitious material-to-sand ratio of 1:3. Initial water absorption and 7- and 28-days compressive strength tests were carried out. The results obtained confirm the possibility of using carbonated kimberlite to replace cement partially, and highlight the benefits of carbonating the kimberlite for such application, and recommendations for future research are suggested. This study demonstrates the potential use of mining tailings to prototype the sequestration of $\mathrm{CO}_{2}$ into sustainable building materials to positively impact the increasing demand for cement-based products.
\end{abstract}

Keywords: $\mathrm{CO}_{2}$ sequestration; kimberlite tailings; mineral carbonation; magnesium carbonates; cement replacement; compressive strength

\section{Introduction}

A contemporary life without cement has been unimaginable for centuries. Cement is a primary building element for infrastructure development and housing, and a gateway to economic growth. The cement industry performs an essential function in advancing living standards worldwide by generating numerous indirect and direct jobs, consequently affording the associated industry with varied economic gains in cascade. Although it has many advantages such as practicality, it is responsible for $8 \%$ of global $\mathrm{CO}_{2}$ emissions. The global cement industry has produced about 2.2 billion tonnes of $\mathrm{CO}_{2}$, and the calcination process accounts for more than half of that amount. Moreover, the third biggest national emitter after China and the United States of America would be the world cement industry [1]. The consumption of cement or other industrial binders raises greenhouse gas emissions because a typical cement plant generates embedded discharges of $0.95 \mathrm{~kg} \mathrm{CO}_{2} \mathrm{~kg}^{-1}$ of 
cement [2]. This unwanted reality will continue for decades to come until a more sustainable alternative is developed.

The global atmospheric temperature is shifting faster now than at any point in modern history, and ways to reduce greenhouse gases in the atmosphere are therefore one of our priorities to fight this climate change [1]. Recent studies and research have focused on the recovery of waste from various industrial sectors that can replace cement up to a certain quantity without compromising strength and durability [2]. When focusing on the mining sector, tailings are equivalent to approximately $99 \%$ of the total mineral excavated, while only 1 to $3 \%$ is concentrated [3]. These tailings are assessed on a scale of billions of tonnes per year regarding waste material, which is a huge sum that causes expensive landfills [4]. In many countries, rapid urbanization has also produced a large quantity of waste that impacts the environment [2]. With the rising demand for industrial waste and housing, it is advantageous to use this waste as a building resource in concrete and brick production [5]. Production of firebricks is a process that is highly energy intensive, and thus contains high embodied energy and carbon footprint [6]. The reduction of $\mathrm{CO}_{2}$ emissions in half was imposed by the "Cement and Technology Roadmap 2009" as a worldwide challenge to be accomplished by 2050 [7]. The increase in demand for cement focuses a lot on finding a better replacement for it. The emphasis on waste recovery has two main reasons: (1) it is inexpensive; and (2) it reduces discharges. A key factor in mineral carbonation is the availability of an abundant source of carbon dioxide, making the construction industry its best host.

Several studies have taken place on the utilization of various waste materials as a component for casting bricks; examples of such waste materials include wastewater sludge [8-10], pharmaceutical waste [11], paper and pulp mill residue [12], municipal solid waste [13], olive industry waste [14-17], and tea waste from processing plants [18], among many others. Research on the utilization of waste materials from steelmaking processes such as stainless-steel slag [19] and Basic Oxygen Furface slag [20] has been considered in the context of $\mathrm{CO}_{2}$ sequestration due to their suitable mineral composition that is reactive with $\mathrm{CO}_{2}$ to form carbonates; such carbonated slags have then been considered to be valorized in the field of construction. Through the Carmex Project [21], processed kimberlite has been identified as appropriate for carbon capture given the high level of mineral carbonation obtained in small aqueous reaction scale and based on extensive life cycle analysis of possible scenarios. Kimberlite is a magnesium- and calcium-rich silicate mineral and is presently stored in tailings ponds due to the remote location of mining operations such as those of De Beers Canada in the Northwest Territories. Using kimberlite for $\mathrm{CO}_{2}$ sequestration and for utilization in building materials thus presents an opportunity to better deal with this waste material, and to also encourage diamond mining from reserves that are not currently economically viable.

Accelerated mineral carbonation has been practiced for years, and its use for carbon capture and storage (CCS) is discussed widely in various research areas [22]. Consumers and industries are already turning toward strategies for combating climate change and adding value to their products via carbon capture and utilization (CCU) technologies. Adding value to commodities through substituting traditional methods for CCU also improves commercial efficiency, together with increasing the environmental advantages of mineralization [23]. Accelerated mineral carbonation processes are energy demanding, and efforts have been made to intensify the reactions, which often require high pressure and temperatures [24], along with pre-treatment of the minerals $[25,26]$ and other reaction additives [27]. Thin-film carbonation, under mild conditions, is a form of accelerated carbonation that results in a moderate carbonation extent, but with low energy consumption [19].

This study presents the properties of processed kimberlite, sourced from a diamond mining operation, before and after being reacted with $\mathrm{CO}_{2}$ in an artificially accelerated mineral carbonation process, and focuses on its use in construction materials such as concrete bricks. The article assesses the influence of the replacement ratio of the kimberlite, and the carbonation conditions the kimberlite was subjected to ( $\% \mathrm{CO}_{2}$, moisture content, and temperature), on the physico-mechanical properties of the bricks (initial water absorption, compressive strength, and stress strain behavior, 
after 7 and 28 days of curing). The study outcomes indicate the potential of treated kimberlite in brick-making for a more sustainable masonry alternative in the construction sector.

\section{Materials and Methods}

\subsection{Kimberlite}

Kimberlite was sourced from Gahcho Kué Diamond Mine, Northwest Territories, Canada, owned by the De Beers Group. The kimberlite received was freshly collected on site, wet, and was classified as fine processed kimberlite (FPK) with a grain size ranging from 3.9 to $62.5 \mu \mathrm{m}$. For the carbonation experiment, it was dried in an oven at $50{ }^{\circ} \mathrm{C}$ for $24 \mathrm{~h}$ and ground by a pestle to attain a powdery form. The elemental composition of the kimberlite was $48.4 \% \mathrm{SiO}_{2}, 27.5 \% \mathrm{MgO}, 9.42 \%$ $\mathrm{Fe}_{2} \mathrm{O}_{3}, 6.77 \% \mathrm{Al}_{2} \mathrm{O}_{3}, 3.0 \% \mathrm{CaO}, 1.79 \% \mathrm{~K}_{2} \mathrm{O}, 0.91 \% \mathrm{P}_{2} \mathrm{O}_{2}$, and $0.584 \% \mathrm{Na}_{2} \mathrm{O}$, determined by wavelength dispersive X-ray fluorescence (WDXRF, Malvern Panalytical, Malvern, United Kingdom).

The X-ray diffraction (XRD) diffractogram of the unreacted kimberlite is presented in Figure 1. According to the XRD analysis, unreacted kimberlite is mainly composed of, in alphabetic order, calcite $\left(\mathrm{CaCO}_{3}\right)$, chrysotile $\left(\mathrm{Mg}_{3} \mathrm{Si}_{2} \mathrm{H}_{4} \mathrm{O}_{9}\right)$, forsterite $\left(\mathrm{Mg}_{2} \mathrm{SiO}_{4}\right)$, microcline $\left(\mathrm{KAlSi}_{3} \mathrm{O}_{8}\right)$, montmorillonite $\left((\mathrm{Na}, \mathrm{Ca})_{0.3}(\mathrm{Al}, \mathrm{Mg})_{2} \mathrm{Si}_{4} \mathrm{O}_{10}(\mathrm{OH})_{2} \cdot \mathrm{nH}_{2} \mathrm{O}\right)$, phlogopite $\left(\mathrm{KMg}_{3}\left(\mathrm{AlSi}_{3} \mathrm{O}_{10}\right)(\mathrm{OH})_{2}\right)$, quartz $\left(\mathrm{SiO}_{2}\right)$, and talc $\left(\mathrm{Mg}_{3} \mathrm{Si}_{4} \mathrm{O}_{10}(\mathrm{OH})_{2}\right)$. This composition is in agreement with the characterization done by Mervine et al. [28] on processed kimberlite from Gahcho Kué. Its volatile content, determined by furnace loss on ignition (LOI) at $950{ }^{\circ} \mathrm{C}$, was $7.12 \mathrm{wt} \%$; such volatiles are attributable mainly to pre-existing carbonates, hydrated silicates, and metal hydroxides. After heat treatment to remove thermally decomposable hydrates and hydroxides, the LOI was reduced to $4.32 \mathrm{wt} \%$, which is attributable to its $\mathrm{CO}_{2}$ content.

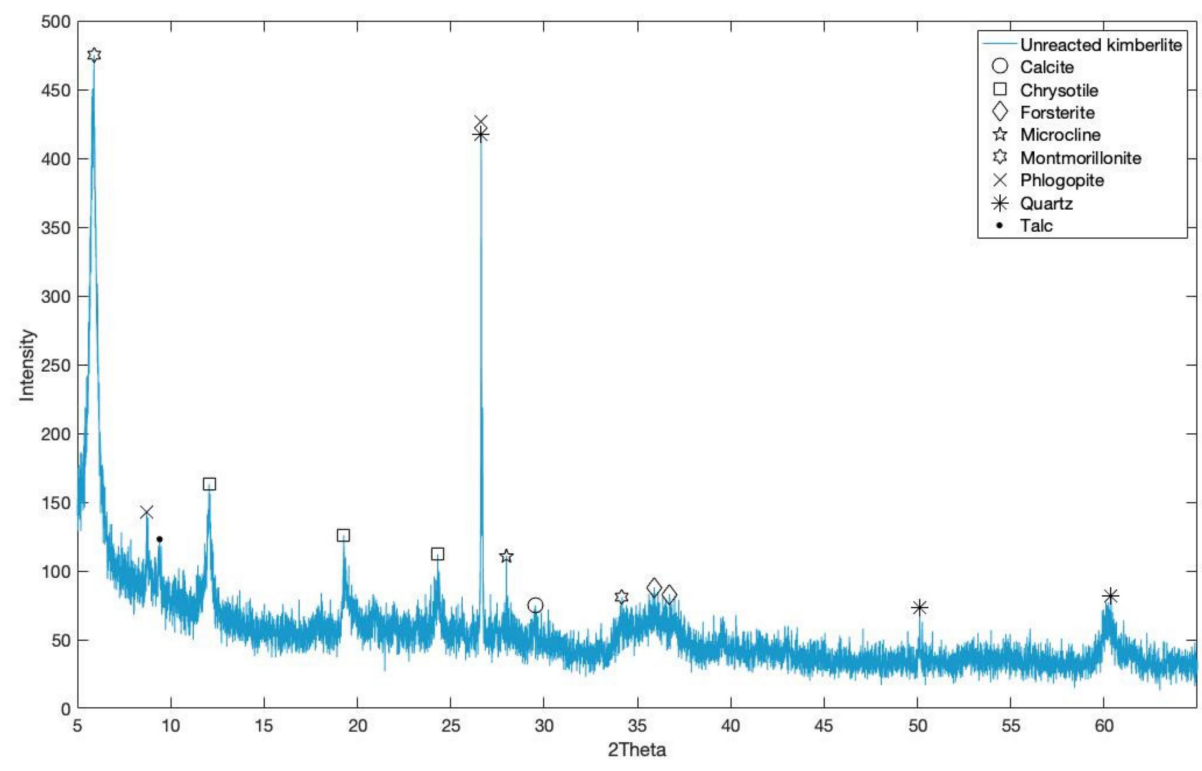

Figure 1. X-ray diffraction (XRD) diffractogram of fine processed kimberlite (FPK), sourced from the Gahcho Kué Diamond Mine, Northwest Territories, Canada.

\subsection{Thin-Film Carbonation}

For thin-film carbonation, a $\mathrm{CO}_{2}$ incubator (Binder C170, Tuttlingen, Germany) was used. Experimental procedures and conditions were adapted from Bodor et al. [29] and Santos et al. [19]. Reaction temperatures of 35 and $50{ }^{\circ} \mathrm{C}, \mathrm{CO}_{2}$ levels of 10 and $20 \%$, and moisture contents of 10,15 , and $20 \mathrm{wt} \%$ were tested. In three stainless steel trays, $60 \mathrm{~g}$ of kimberlite was wetted using ultrapure water $(18.2 \mathrm{M} \Omega \cdot \mathrm{cm})$ to attain moisture contents of 10,15, and $20 \mathrm{wt} \%$ for each sample. Around $50 \mathrm{~g}$ of kimberlite was spread on the bottom of the trays to make a thin layer, and $10 \mathrm{~g}$ was put in a 
small crucible. The trays and crucibles were put into a $\mathrm{CO}_{2}$ incubator for $144 \mathrm{~h}$. Every $24 \mathrm{~h}$, the small crucible that contained $10 \mathrm{~g}$ of wet kimberlite was put in an oven $\left(60^{\circ} \mathrm{C}\right)$ for $2-3 \mathrm{~h}$ to calculate the loss in moisture content during the $24 \mathrm{~h}$ in the incubator and subsequently determine the amount of ultrapure water required to add to the trays to maintain their initial moisture content. It is important to check their moisture content at least once in every $24 \mathrm{~h}$ because the heat produced during the exothermic mineral carbonation process can increase the chances of the samples drying out [30]. At the same time, the content that remained in each tray was lightly deagglomerated by using a pestle to increase its surface area (area of reactivity) as carbonation can lead to cementitious behavior of the stationary material, which decreases powder surface area and hinders the carbonation progression [31]. Once the content in the tray was rewetted to its initial moisture content, it was put back in the $\mathrm{CO}_{2}$ incubator for another $24 \mathrm{~h}$. The same steps were repeated until the total amount of time that each tray spent in the incubator reached $144 \mathrm{~h}$.

Mineral carbonation is not widely practiced due to process limitations including high energy intensity, low reaction conversion, and slow reaction kinetics [32]. Hence, a mild carbonation treatment was utilized in this study, despite its reduced ability in sequestering $\mathrm{CO}_{2}$. The rationale is that it is more feasible to reach lower carbonation conversion with less energy expenditure than to aim for high carbonation conversions but with much higher energy demand, which reduces the net $\mathrm{CO}_{2}$ sequestration achievable.

The carbonated kimberlite samples were mineralogically examined through the furnace test and XRD analysis. The furnace test was conducted with the samples' weights measured at two temperatures, $300{ }^{\circ} \mathrm{C}$ and $950{ }^{\circ} \mathrm{C}$. The weight loss up to $300{ }^{\circ} \mathrm{C}$ is attributable to chemically bonded water (hydrates and hydroxides), some of which may have formed during carbonation, and the weight loss between $300{ }^{\circ} \mathrm{C}$ and $950{ }^{\circ} \mathrm{C}$ is attributable to $\mathrm{CO}_{2}$ released from Ca- and $\mathrm{Mg}$-carbonates.

\subsection{Casting of Bricks}

The samples collected after $144 \mathrm{~h}$ from the incubator were used as a replacement for cement in concrete brick making. The samples were stored in separate containers. The various alterations in the experiments were used to create 12 different levels of carbonated kimberlite. These samples were used to cast bricks and compared with a control brick (industrial standard) according to ASTM standards [33].

The mix design of the concrete brick determines its strength. The ratio of cementitious material to sand was fixed as 1:3 and the water-to-cement ratio was 0.6:1 to produce industrial standard bricks. The kimberlite was used as a 10\% replacement of cement in our testing. The main constituents used for casting a concrete brick were $600 \mathrm{~g}$ of cement and kimberlite as the binding material (540 $\mathrm{g}$ cement and $60 \mathrm{~g}$ of kimberlite), $1800 \mathrm{~g}$ of sand as its aggregate (to fill the voids and increase the density of the brick), and $360 \mathrm{~mL}$ of water for the chemical reaction in the mixture. The quantities were carefully measured using a weight balance and mixed together in a container to obtain a plastic mix. The components were mixed together with the help of a hand mixer. The brick mold was coated with grease and the mixture was filled in three steps with uniform compaction, as shown in Figure 2 . The brick dimension was $20 \mathrm{~cm}$ (length) $\times 10 \mathrm{~cm}$ (width) $\times 6 \mathrm{~cm}$ (height). The molded bricks were placed to set/dry in the $\mathrm{CO}_{2}$ incubator at $35^{\circ} \mathrm{C}$ and $10 \% \mathrm{CO}_{2}$ for $24 \mathrm{~h}$, allowing for $\mathrm{CO}_{2}$ dissolution into porewater and some early strength-producing carbonation to occur prior to pore drying. The set, dried bricks were then demolded, weighed on a weighing balance, and numbered as specified in Table 1. 
Table 1. The brick numbers that specify its curing duration and the carbonated kimberlite sample used.

\begin{tabular}{|c|c|}
\hline Brick Number & Carbonated Kimberlite Material-10\% Replacement \\
\hline 1 (7 days) & \multirow{2}{*}{$10 \%$ Moisture Content, $10 \% \mathrm{CO}_{2}, 35^{\circ} \mathrm{C}$} \\
\hline 1 (28 days) & \\
\hline 2 (7 days) & \multirow{2}{*}{$15 \%$ Moisture Content, $10 \% \mathrm{CO}_{2}, 35^{\circ} \mathrm{C}$} \\
\hline 2 (28 days) & \\
\hline 3 (7 days) & \multirow{2}{*}{$20 \%$ Moisture Content, $10 \% \mathrm{CO}_{2}, 35^{\circ} \mathrm{C}$} \\
\hline 3 (28 days) & \\
\hline 4 (7 days) & \multirow{2}{*}{$10 \%$ Moisture Content, $20 \% \mathrm{CO}_{2}, 35^{\circ} \mathrm{C}$} \\
\hline 4 (28 days) & \\
\hline 5 (7 days) & \multirow{2}{*}{$15 \%$ Moisture Content, $20 \% \mathrm{CO}_{2}, 35{ }^{\circ} \mathrm{C}$} \\
\hline 5 (28 days) & \\
\hline 6 (7 days) & \multirow{2}{*}{$20 \%$ Moisture Content, $20 \% \mathrm{CO}_{2}, 35^{\circ} \mathrm{C}$} \\
\hline 6 (28 days) & \\
\hline 7 (7 days) & \multirow{2}{*}{$10 \%$ Moisture Content, $10 \% \mathrm{CO}_{2}, 50{ }^{\circ} \mathrm{C}$} \\
\hline 7 (28 days) & \\
\hline 8 (7 days) & \multirow{2}{*}{$15 \%$ Moisture Content, $10 \% \mathrm{CO}_{2}, 50^{\circ} \mathrm{C}$} \\
\hline 8 (28 days) & \\
\hline 9 (7 days) & \multirow{2}{*}{$20 \%$ Moisture Content, $10 \% \mathrm{CO}_{2}, 50{ }^{\circ} \mathrm{C}$} \\
\hline 9 (28 days) & \\
\hline 10 (7 days) & \multirow{2}{*}{$10 \%$ Moisture Content, $20 \% \mathrm{CO}_{2}, 50{ }^{\circ} \mathrm{C}$} \\
\hline 10 (28 days) & \\
\hline 11 (7 days) & \multirow{2}{*}{$15 \%$ Moisture Content, $20 \% \mathrm{CO}_{2}, 50{ }^{\circ} \mathrm{C}$} \\
\hline 11 (28 days) & \\
\hline 12 (7 days) & \multirow{2}{*}{$20 \%$ Moisture Content, $20 \% \mathrm{CO}_{2}, 50^{\circ} \mathrm{C}$} \\
\hline 12 (28 days) & \\
\hline
\end{tabular}

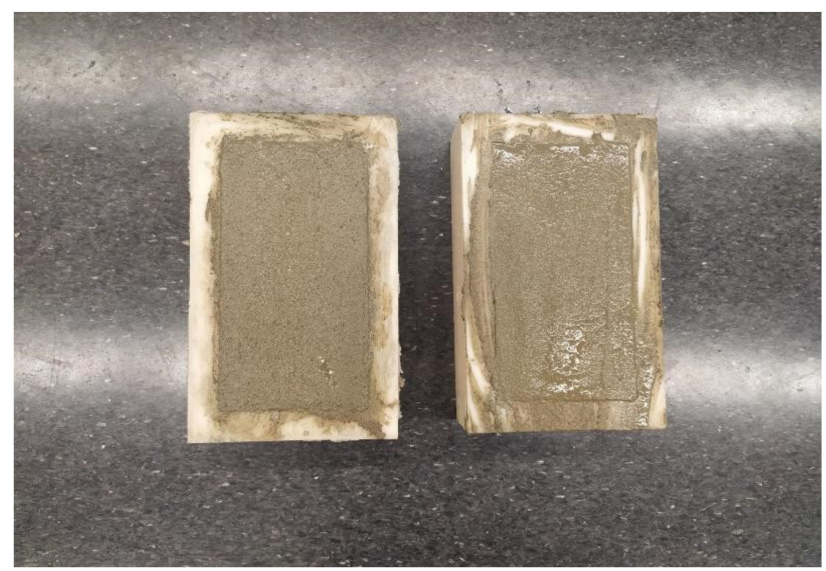

Figure 2. Compacted mix in the brick molds.

For comparison to the industrial standard, two cement bricks were cast and named as control 1 and control 2. Additionally, control bricks were cast with unreacted kimberlite as $10 \%$ and $20 \%$ replacement to cement, namely control 10 and control 20, respectively. 


\subsection{Initial Water Absorption Test}

The initial weights of the demolded bricks were noted as W1. Then, the bricks were immersed in water for curing, as shown in Figure 3. The time of immersion was noted, and the brick was removed from water after $24 \mathrm{~h}$. The brick was set to air dry, and the surface of the brick was wiped with a cloth to remove any moisture and water from the brick surface. Then, the brick was weighed again in the weighing balance as W2. The gain in weight was calculated by Equation (1) to give the initial water absorption capacity of the brick. Bricks were then returned to water for immersion curing for another six or 27 days, according to Table 1 .

$$
\text { Initial water absorption capacity of brick }(\%)=\{(\mathrm{W} 2-\mathrm{W} 1) \times 100 / \mathrm{W} 1\}
$$

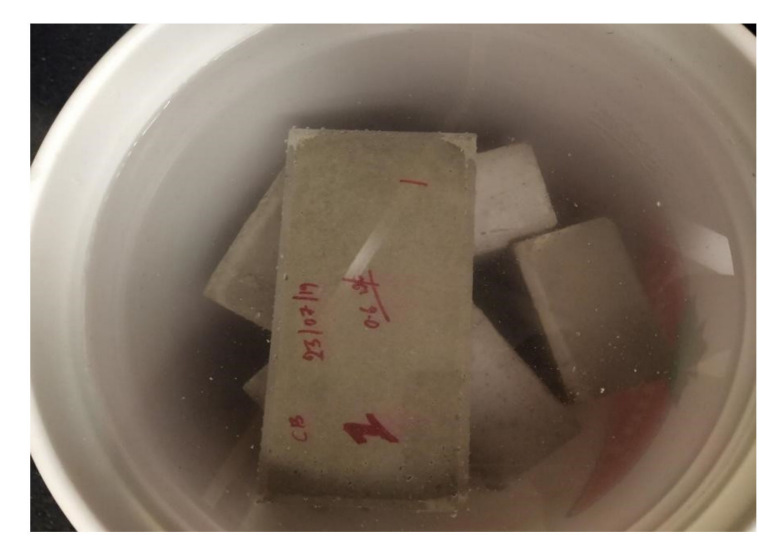

Figure 3. Immersed bricks for the water absorption test.

\subsection{Compressive Strength Test}

The compressive strength of the bricks helps us to understand the extent to which the kimberlite can be valorized as a building material. The concrete brick compressive strength testing was done in accordance with the ASTM C 67 code in an MTS ${ }^{\circledR}$ compression machine (MTS, Eden Prairie, MN, USA), as shown in Figure 4. Two metal plates, the size of the top face of the brick, were used to distribute the stress throughout the brick while under compression. The strain rate was fixed at $5 \mathrm{~mm}$ per minute and the load rate of four tonnes per minute. The brick's surface was smoothened and kept under compression. The test was stopped once the brick cracked or the maximum stress was attained.

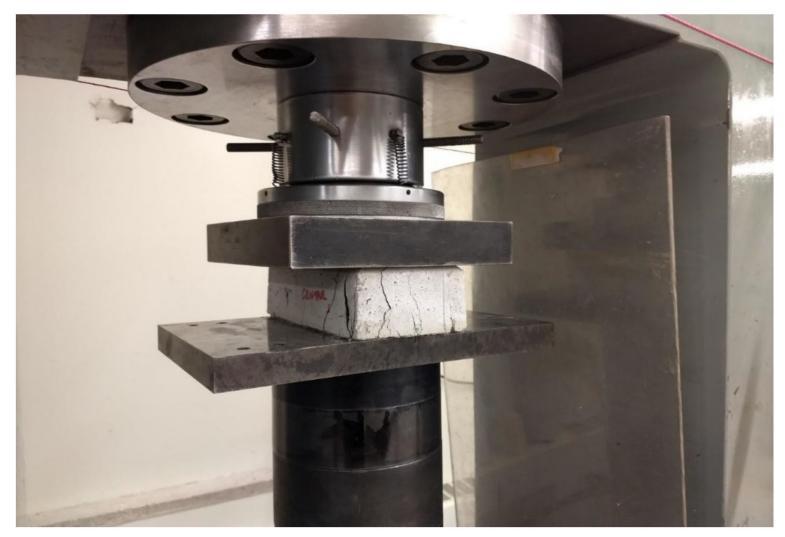

Figure 4. Compression test in the $\mathrm{MTS}^{\circledR}$ compression machine. 


\section{Results and Discussion}

\subsection{Kimberlite Carbonation}

To determine the properties of $\mathrm{CO}_{2}$ sequestered kimberlite, the furnace test and XRD analysis were conducted. According to the furnace test, the maximum weight loss caused by the release of $\mathrm{CO}_{2}$ was achieved by the kimberlite sample with a moisture content of $20 \mathrm{wt} \%$ carbonated at $35^{\circ} \mathrm{C}$ and under $20 \% \mathrm{CO}_{2}$. This result was expected as high temperature $\left(50^{\circ} \mathrm{C}\right)$ reduces the solubility of $\mathrm{CO}_{2}$ compared to that at the lower temperature $\left(35^{\circ} \mathrm{C}\right)$ [19]. Variation in moisture content of the material did not show an apparent influence on the amount of $\mathrm{CO}_{2}$ sequestered in each sample. In this experiment, moisture contents of 10, 15, and $20 \mathrm{wt} \%$ were chosen for assessment because it had been reported that moisture content between 10 and $35 \mathrm{wt} \%$ should be maintained to proceed with thin-film carbonation [19]. The distinct effect of varying moisture content was lacking due to manual wetting of the material resulting in heterogeneous moisture content within the same batch of kimberlite. Table 2 provides the weight percentage of $\mathrm{CO}_{2}$ released by each kimberlite sample, which corresponds to the carbonates present after carbonation. It should be noted that these amounts of $\mathrm{CO}_{2}$ present in the samples do not directly reflect the amount of $\mathrm{CO}_{2}$ sequestered through the thin-film carbonation as they include the amount of $\mathrm{CO}_{2}$ that pre-existed prior to carbonation ( $\left.4.32 \mathrm{wt} \%\right)$, due to the carbonate content of kimberlite (mainly calcite). Thus, the greatest gain in $\mathrm{CO}_{2}$ was approximately $3.7 \mathrm{wt} \%$ for the sample carbonated at $35^{\circ} \mathrm{C}, 20 \% \mathrm{CO}_{2}$ concentration, and $20 \%$ moisture content.

Table 2. The amount of $\mathrm{CO}_{2}$ released during furnace test from the unreacted and thin-film carbonated kimberlite.

\begin{tabular}{|c|c|c|c|}
\hline \multicolumn{3}{|c|}{ Carbonation Conditions } & \multirow{2}{*}{$\begin{array}{l}\text { Carbonated Kimberlite } \\
\mathrm{CO}_{2} \text { Content (wt } \% \text { d.b.) }\end{array}$} \\
\hline Temperature $\left({ }^{\circ} \mathrm{C}\right)$ & $\mathrm{CO}_{2}$ Concentration (vol\%) & Moisture Content (wt\% w.b.) & \\
\hline Unreacted & - & - & 4.32 \\
\hline \multirow{3}{*}{35} & \multirow{3}{*}{10} & 10 & 7.67 \\
\hline & & 15 & 7.92 \\
\hline & & 20 & 7.76 \\
\hline \multirow{3}{*}{35} & \multirow{3}{*}{20} & 10 & 7.94 \\
\hline & & 15 & 7.96 \\
\hline & & 20 & 8.04 \\
\hline \multirow{3}{*}{50} & \multirow{3}{*}{10} & 10 & 7.52 \\
\hline & & 15 & 7.53 \\
\hline & & 20 & 7.35 \\
\hline \multirow{3}{*}{50} & \multirow{3}{*}{20} & 10 & 7.75 \\
\hline & & 15 & 7.62 \\
\hline & & 20 & 7.47 \\
\hline
\end{tabular}

d.b.: dry basis; w.b.: wet basis.

Figure 5 shows the XRD diffractograms that depict the formation of hydrated magnesium carbonates in the form of nesquehonite $\left(\mathrm{MgCO}_{3} \cdot 3 \mathrm{H}_{2} \mathrm{O}\right)$ and lansfordite $\left(\mathrm{MgCO}_{3} \cdot 5 \mathrm{H}_{2} \mathrm{O}\right)$ in thin-film carbonated kimberlite at 35 and $50{ }^{\circ} \mathrm{C}$. It is predicted that the additional amount of calcium carbonates such as calcite precipitated due to carbonation; however, this additional formation is not detectable by qualitative XRD analysis as calcite already pre-existed in the unreacted kimberlite. Some carbonates that form under mild conditions can also be amorphous, and hence undetectable by XRD while being part of the $\mathrm{CO}_{2}$ released during the furnace test. Formation of nesquehonite and lansfordite was exhibited in most carbonated kimberlite samples, with certain samples containing larger peaks of the former, which is more thermodynamically stable, and certain samples containing larger peaks of the latter, which is less stable thermodynamically. The formation of nesquehonite in samples carbonated at $35{ }^{\circ} \mathrm{C}$ and $50{ }^{\circ} \mathrm{C}$ is in agreement with results obtained in published studies, which have elucidated that nesquehonite precipitates at temperatures ranging from $25^{\circ} \mathrm{C}$ to $55^{\circ} \mathrm{C}[34,35]$. Lansfordite is known to convert to nesquehonite above $10^{\circ} \mathrm{C}$, but has been reported to co-occur with nesquehonite in certain 
ambient and accelerated carbonation systems [36,37], as it can be kinetically favored as a precursor carbonate phase under mild conditions. On the other hand, hydromagnesite $\left(\mathrm{Mg}_{5}\left(\mathrm{CO}_{3}\right)_{4}(\mathrm{OH})_{2} \cdot 4 \mathrm{H}_{2} \mathrm{O}\right)$ and magnesite $\left(\mathrm{MgCO}_{3}\right)$ were not observed as they are known to precipitate at higher temperatures of $60-95^{\circ} \mathrm{C}$ and $105^{\circ} \mathrm{C}$, respectively.

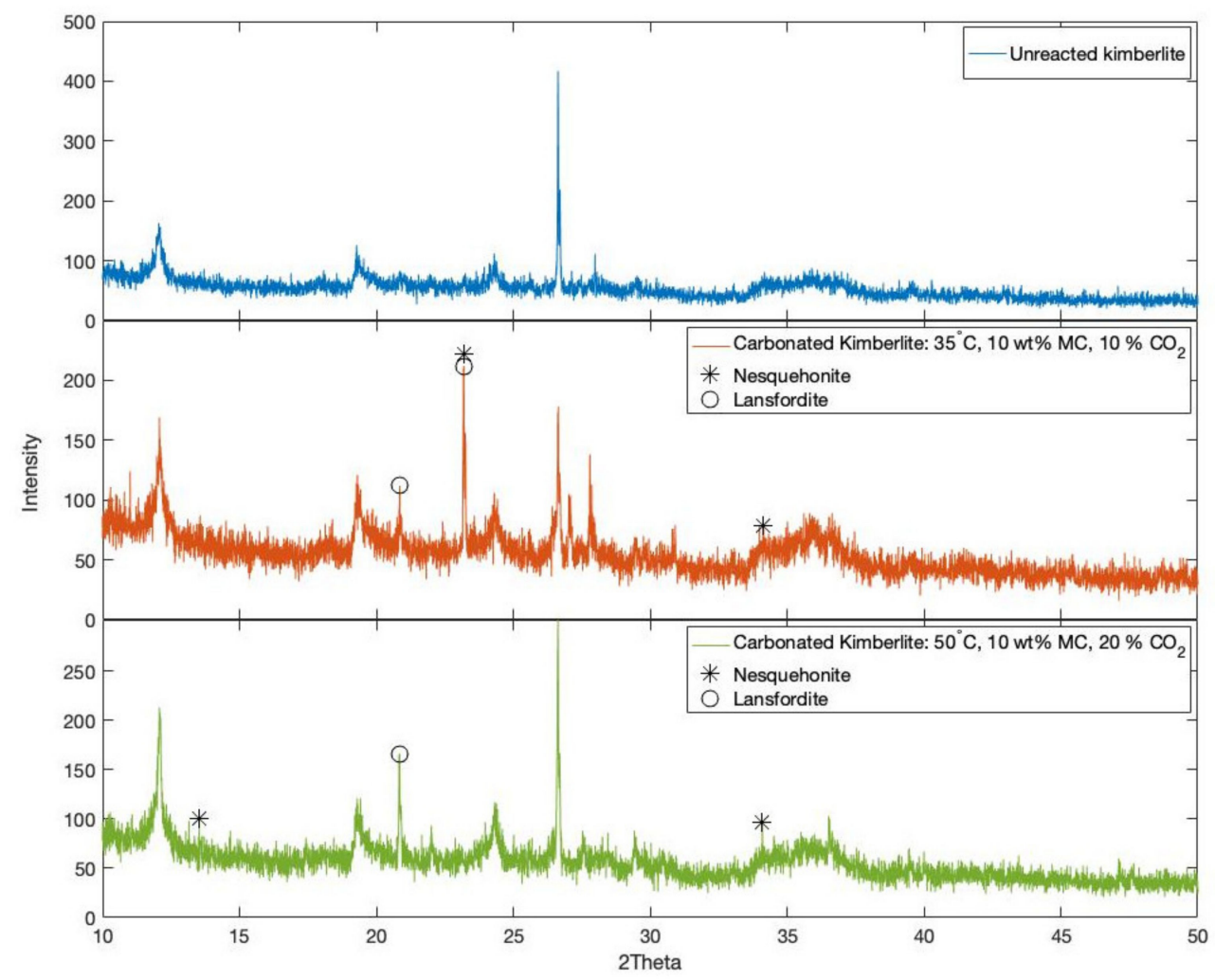

Figure 5. Comparison between the XRD diffractograms of unreacted kimberlite and thin-film carbonated kimberlite at $35{ }^{\circ} \mathrm{C}, 10 \mathrm{wt} \%$ moisture content, and $10 \% \mathrm{CO}_{2}$ concentration and at $50{ }^{\circ} \mathrm{C}, 10 \mathrm{wt} \%$ moisture content, and $20 \% \mathrm{CO}_{2}$ concentration.

\subsection{Binding Properties of Kimberlite}

The two ternary diagrams in Figure 6 show the kimberlite's elemental composition determined by WDXRF according to two different ternary systems. The first system consists of $\mathrm{CaO}_{2} \mathrm{Al}_{2} \mathrm{O}_{3}$, and $\mathrm{SiO}_{2}$, and the second consists of $\mathrm{CaO}+\mathrm{MgO}+\mathrm{Al}_{2} \mathrm{O}_{3}, \mathrm{Fe}_{2} \mathrm{O}_{3}$, and $\mathrm{SiO}_{2}$. These systems contain the fundamental compounds that provide the pozzolanic properties of a mineral, and used to compare pozzolanic properties between different materials (as shown in Figure 7). By comparing Figures $6 \mathrm{a}$ and $7 \mathrm{a}$, it can be said that kimberlite is comparable to fly ashes and natural pozzolanas (volcanic ash) in terms of its chemical composition. Its texture and fineness are likewise comparable, and this helps in reducing the voids in the brick matrix and thus increases the strength and bulk density of the brick. Comparing Figures $6 \mathrm{~b}$ and $7 \mathrm{~b}$, kimberlite is comparable to low iron content steel and copper slags, which is desirable to avoid rust coloration and minimize specific density of the brick. 

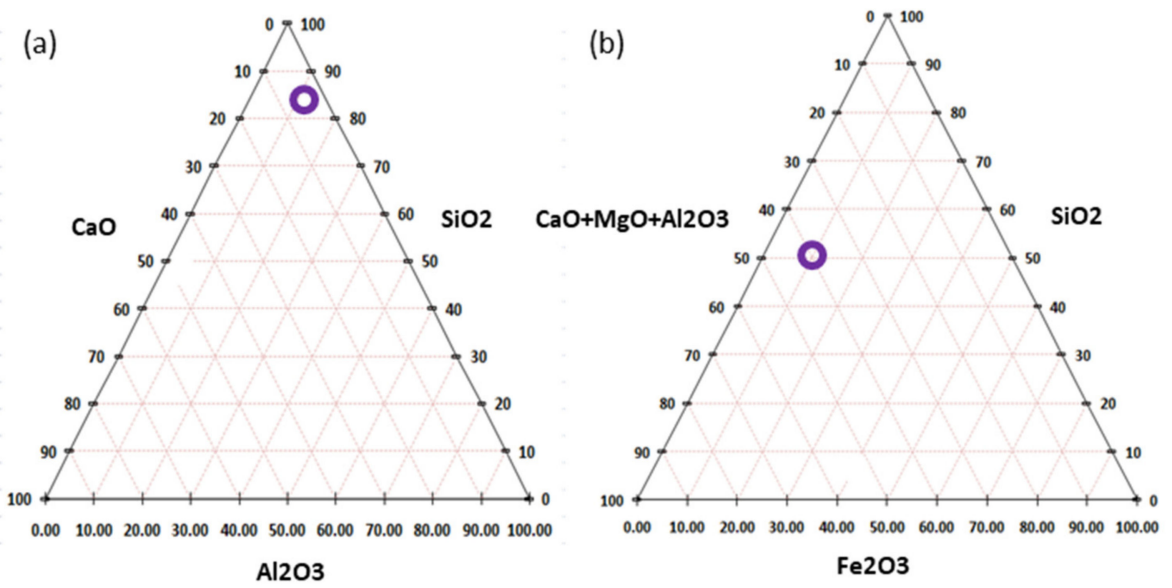

Figure 6. Ternary diagrams of kimberlite's elemental composition (circles). (a) $\mathrm{SiO}_{2}, \mathrm{CaO}$ and $\mathrm{Al}_{2} \mathrm{O}_{3}$ system; (b) $\mathrm{Fe}_{2} \mathrm{O}_{3}, \mathrm{CaO}+\mathrm{MgO}+\mathrm{Al}_{2} \mathrm{O}_{3}$, and $\mathrm{SiO}_{2}$ system.
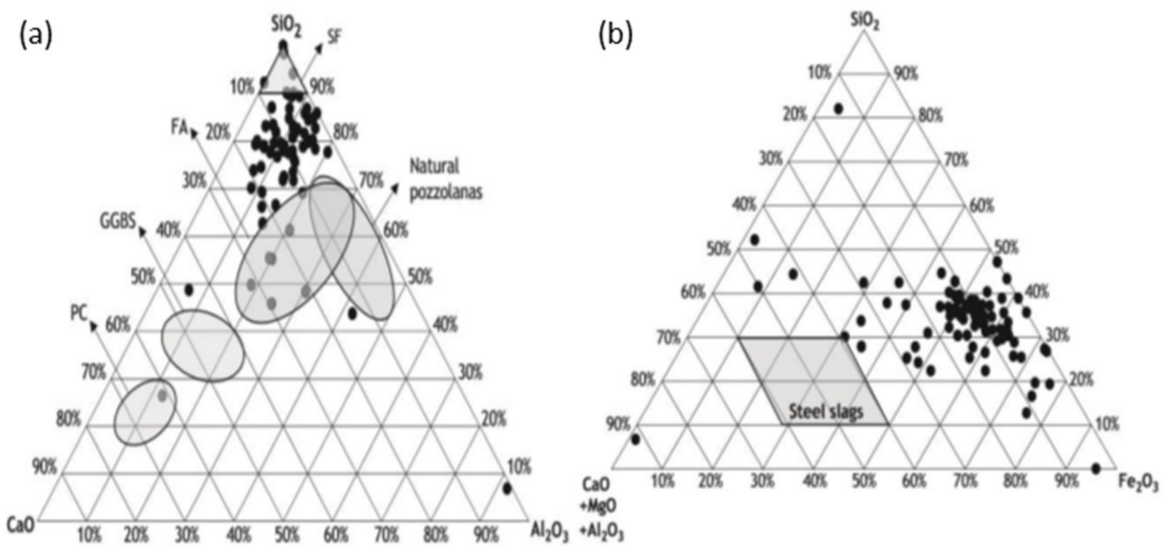

Figure 7. Ternary diagrams for other existing binder materials (a) and steel slag (b), where dots represent copper slag compositions [38]. Reused with permission from Elsevier (License Number 4842140657812).

Furthermore, according to ASTM C618 [39], the criteria to be satisfied to act as a pozzolanic material is that the total amount of $\mathrm{SiO}_{2}, \mathrm{Al}_{2} \mathrm{O}_{3}$, and $\mathrm{Fe}_{2} \mathrm{O}_{3}$ should be a minimum of $70.0 \%$ of the total chemical composition, and loss on ignition should be at most 10.0\%. From our results from the WDXRF, the sum of these oxide constituents was $64.59 \%$. Though the sum percentage was less when compared to the criteria, the carbonation of molded bricks in the $\mathrm{CO}_{2}$ incubator for $24 \mathrm{~h}$, prior to demolding, can help in the production of carbonates that contribute to strength development [40].

\subsection{Initial Water Absorption of Bricks}

The permeability of water through capillary action and the water retention capacity of the bricks highly define its durability. Water absorption can also change the water-to-binder ratio and affect the modulus of elasticity of the brick. The amount of water absorption is also determined by the type of aggregate. Kimberlite is fine in nature when ground, and has a high composition of $\mathrm{SiO}_{2}$, making it a possible alternative for use in concrete as well as an aggregate substitute for sand, which is a finite natural resource and scarce in some regions.

Table 3 presents the calculated initial water absorption of the bricks. The test results showed that a minimum amount of water was absorbed into the pores and cement matrix of the bricks. It proved that there was a low volume of air voids, and thus the bricks were densely packed. The standard specifies that the water absorption for bricks should be less than $7 \%$ to have high durability and resistance to 
freeze and thaw effect. From the Table 3 results, it is clear that the initial water absorption was less than $2 \%$, thus would be expected to be durable and resistant to the heat and thaw effect.

Table 3. Initial water absorption of the kimberlite bricks.

\begin{tabular}{|c|c|c|c|}
\hline Brick Number & Initial Weight (g) & Weight after 24 h (g) & Initial Water Absorption (\%) \\
\hline 1 (7 days) & 2445.15 & 2471.95 & 1.096 \\
\hline 1 (28 days) & 2464.87 & 2494.95 & 1.220 \\
\hline 2 (7 days) & 2490.21 & 2523.64 & 1.342 \\
\hline 2 (28 days) & 2512.21 & 2544.84 & 1.299 \\
\hline 3 (7 days) & 2463.27 & 2497.16 & 1.376 \\
\hline 3 (28 days) & 2479.84 & 2514.87 & 1.413 \\
\hline 4 (7 days) & 2558.10 & 2597.15 & 1.526 \\
\hline 4 (28 days) & 2587.64 & 2623.46 & 1.384 \\
\hline 5 (7 days) & 2561.48 & 2590.66 & 1.139 \\
\hline 5 (28 days) & 2489.00 & 2518.87 & 1.200 \\
\hline 6 (7 days) & 2503.73 & 2539.11 & 1.413 \\
\hline 6 (28 days) & 2551.33 & 2581.85 & 1.196 \\
\hline 7 (7 days) & 2581.85 & 2605.44 & 0.914 \\
\hline 7 (28 days) & 2581.57 & 2606.61 & 0.970 \\
\hline 8 (7 days) & 2566.82 & 2591.55 & 0.963 \\
\hline 8 (28 days) & 2553.44 & 2578.07 & 0.965 \\
\hline 9 (7 days) & 2471.97 & 2500.82 & 1.167 \\
\hline 9 (28 days) & 2541.44 & 2570.81 & 1.156 \\
\hline 10 (7 days) & 2679.80 & 2718.45 & 1.442 \\
\hline 10 (28 days) & 2515.91 & 2549.81 & 1.347 \\
\hline 11 (7 days) & 2536.43 & 2568.78 & 1.275 \\
\hline 11 (28 days) & 2580.04 & 2611.12 & 1.205 \\
\hline 12 (7 days) & 2554.70 & 2584.45 & 1.164 \\
\hline 12 (28 days) & 2563.73 & 2597.85 & 1.331 \\
\hline
\end{tabular}

\subsection{Compressive Strength of Bricks}

According to the ASTM standards, the difference in strength between the 28th and 7th day concrete cement block should be $33.33 \%$. This trend was witnessed throughout the samples, on average, with very few in deviation. Thus, the results plotted in Figure 8 are deemed reliable. For reference, the typical required compressive strength of masonry bricks at 28 days, according to the Canadian Concrete Masonry Producers Association, is between 15 and $40 \mathrm{MPa}$, mainly depending on the content of cement and the content and type of aggregate content, and aggregate type [41]. Typically, unit compressive strengths at 28 days can range from $15 \mathrm{MPa}$ to $40 \mathrm{MPa}$. The ASTM specifies a minimum compressive strength from 10.3 to $55.2 \mathrm{MPa}$ for applications ranging from lightest duty (building brick under negligible weathering) to strictest duty (paving brick under severe weathering), respectively [42]. 

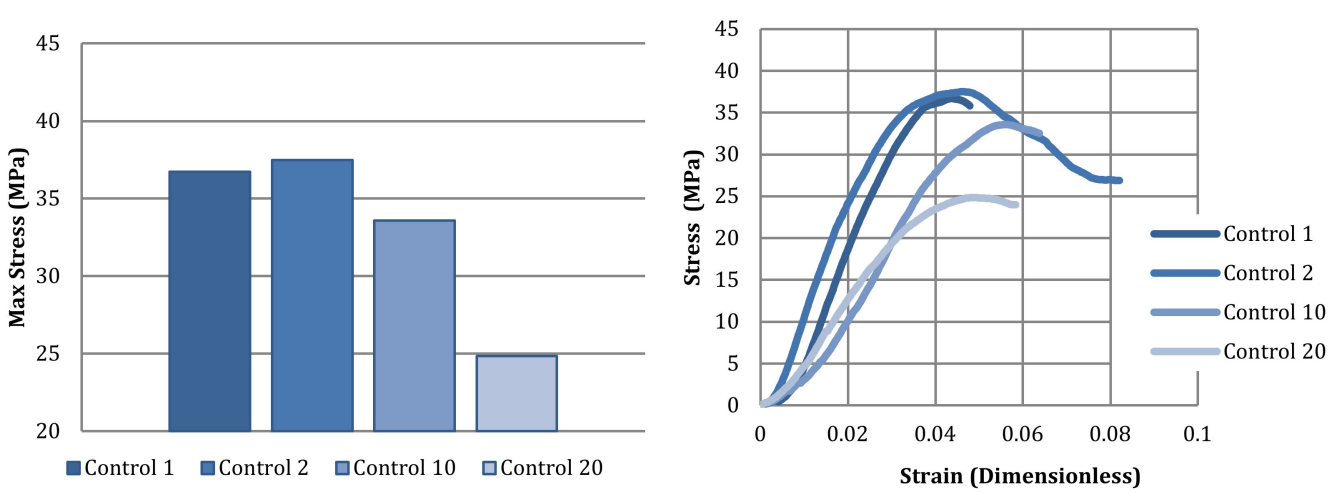

(a)
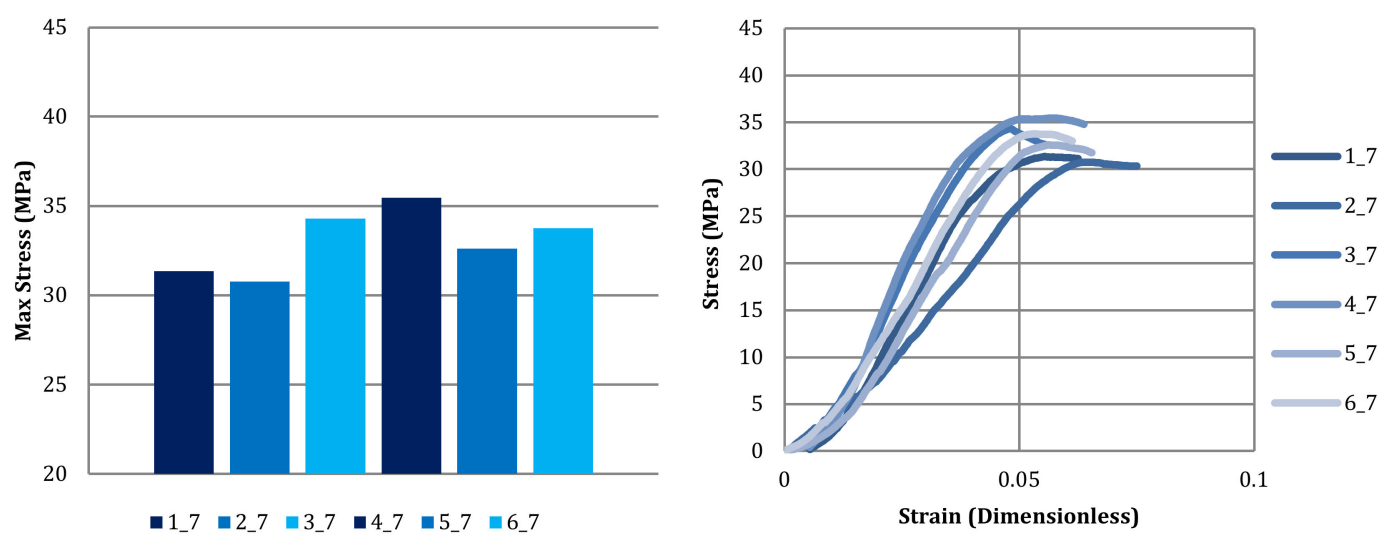

(b)
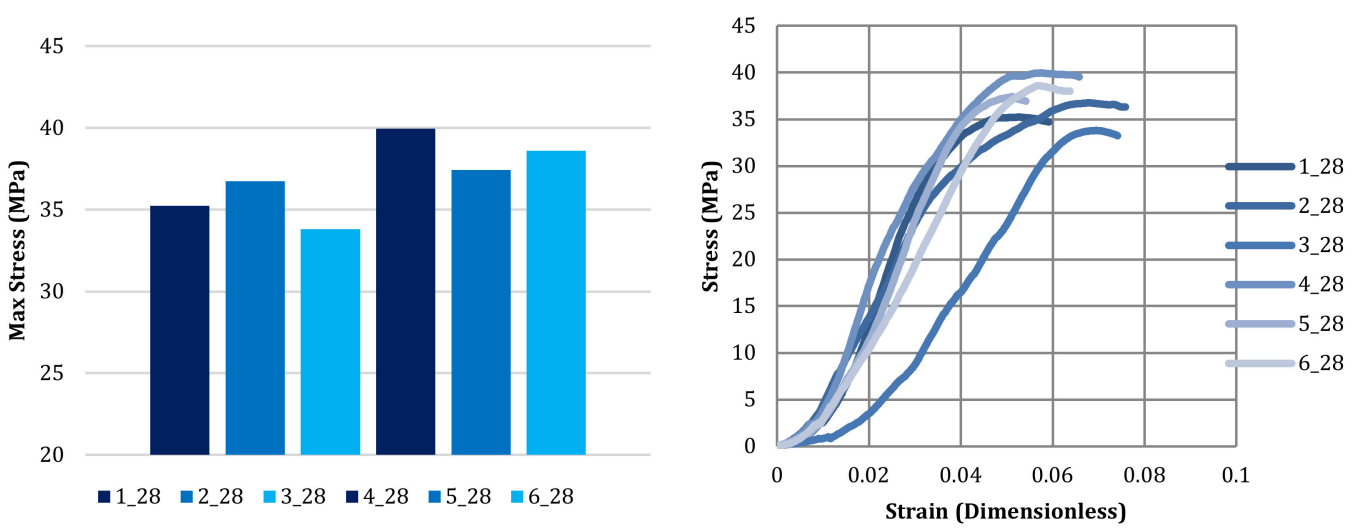

(c)

Figure 8. Cont. 

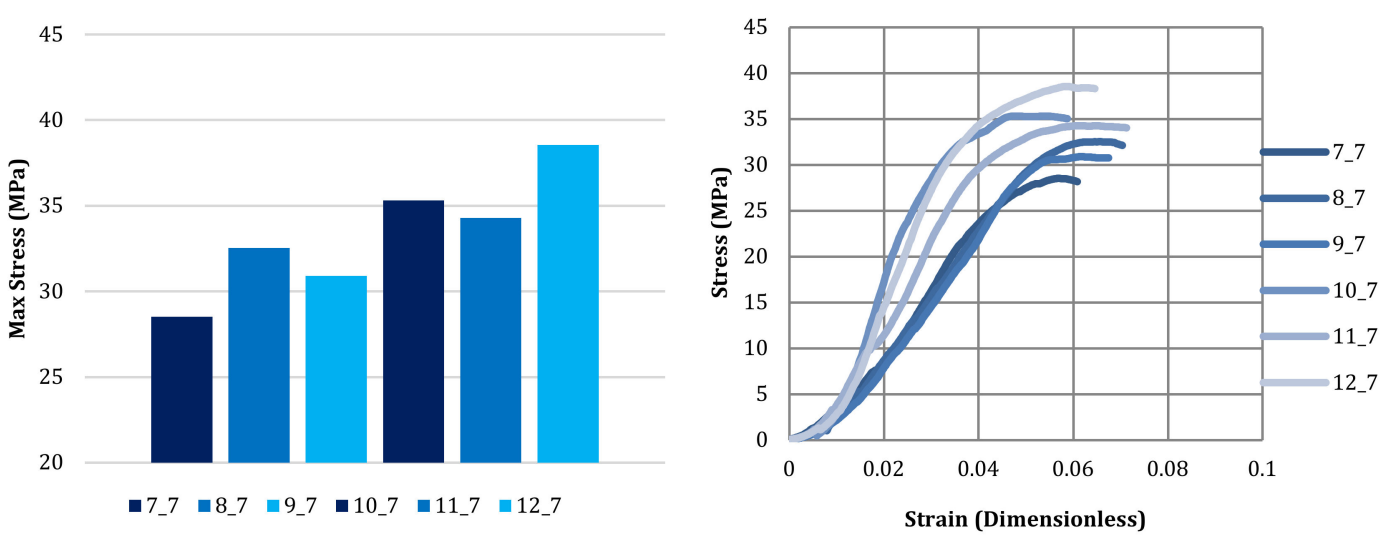

(d)
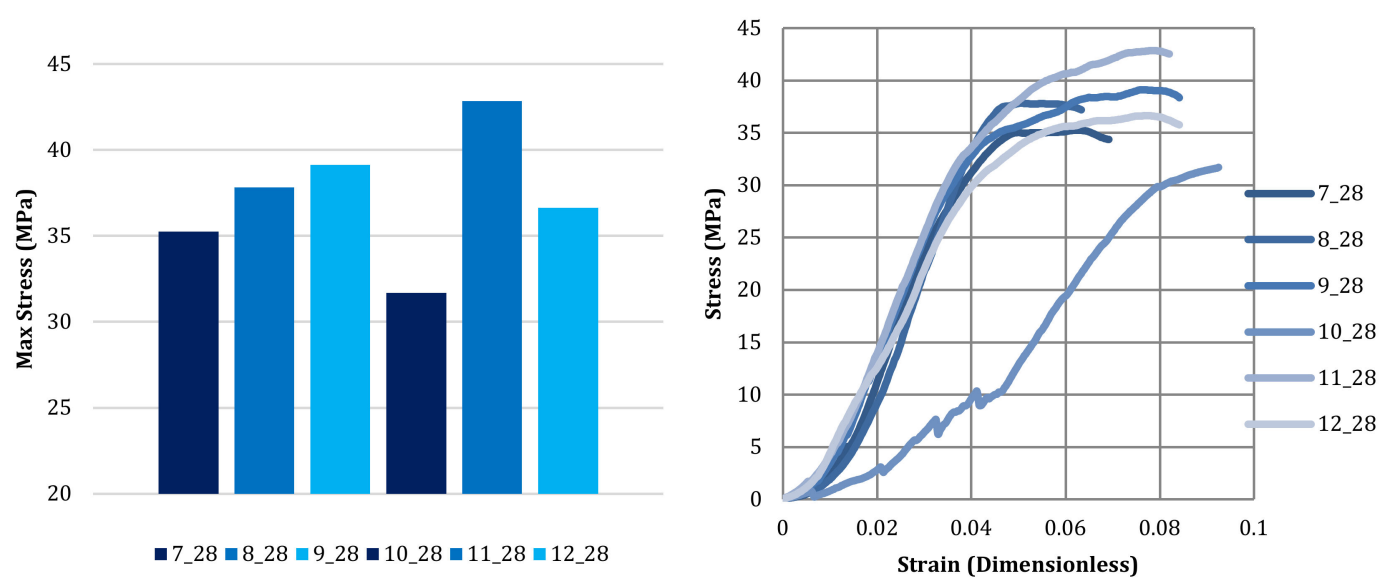

(e)
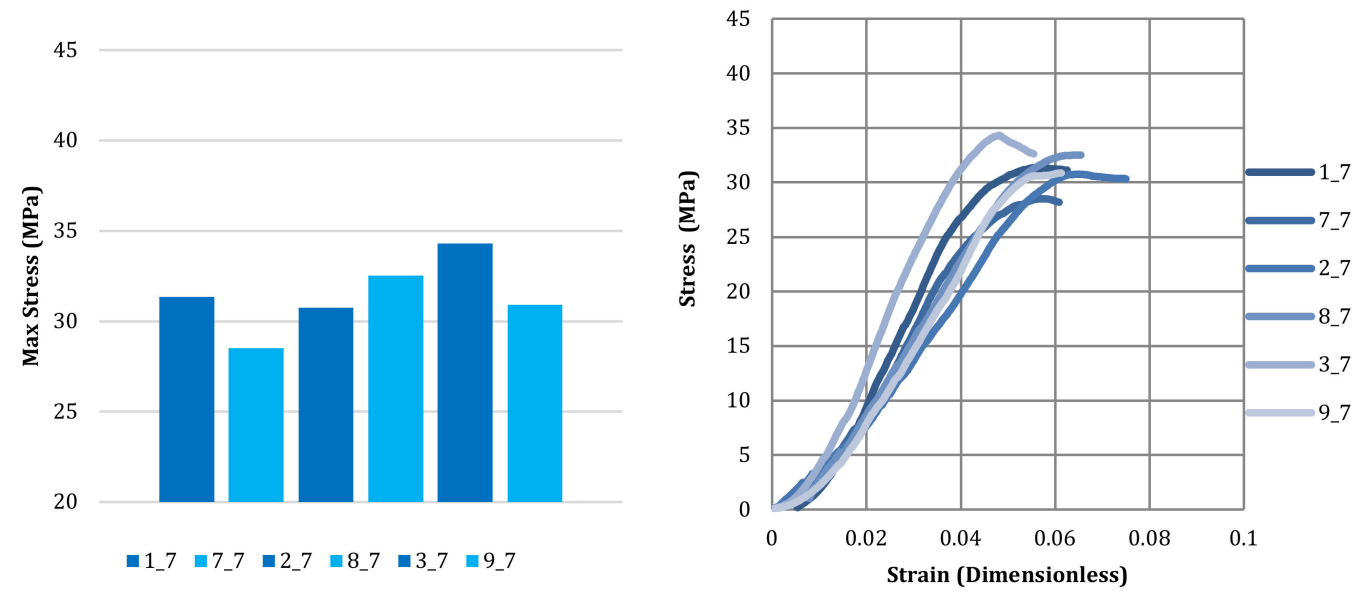

(f)

Figure 8. Cont. 

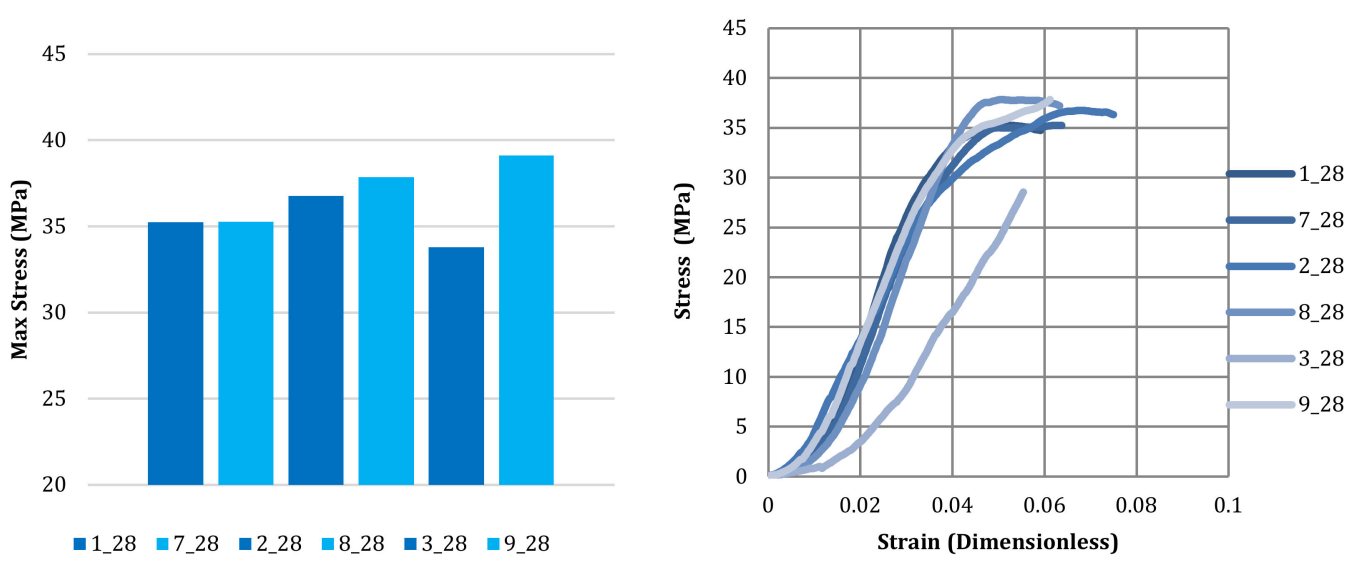

$(\mathrm{g})$
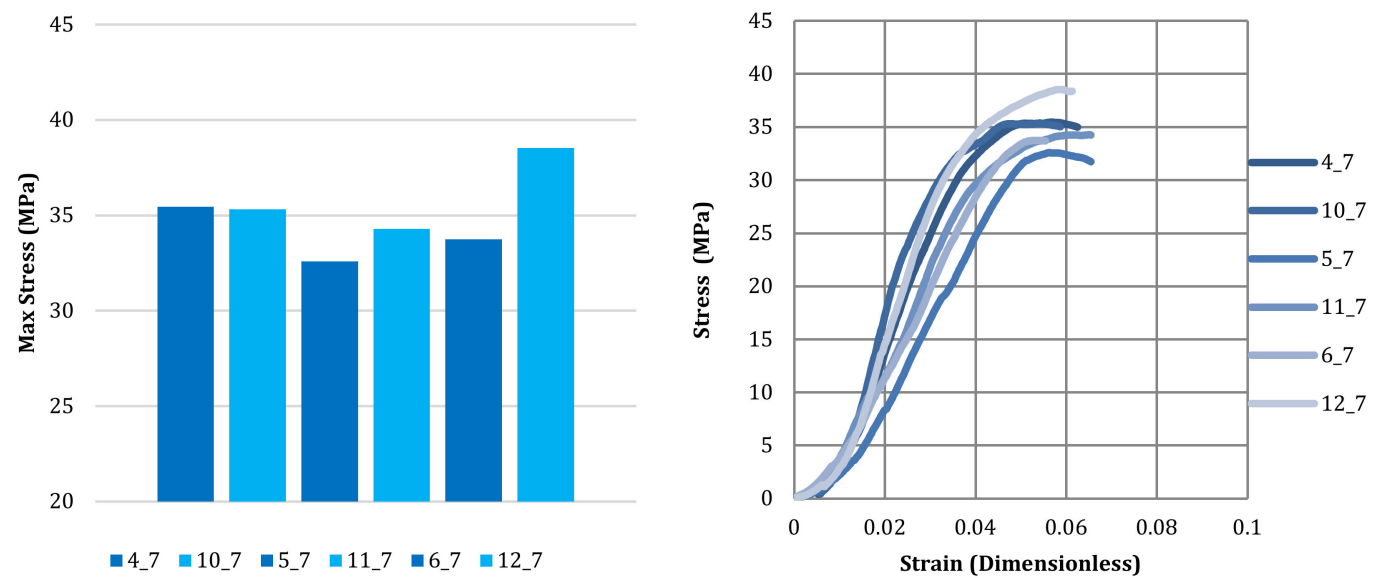

(h)
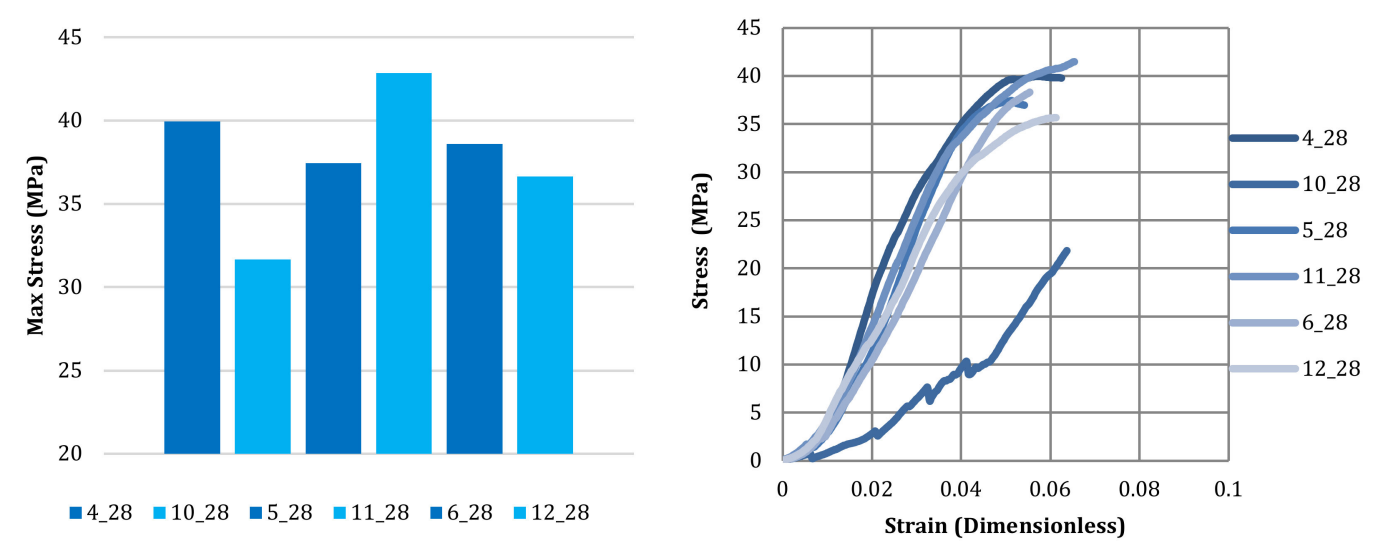

(i)

Figure 8. (a) Comparing the compressive strength and stress strain curves of the standard (controls 1 and 2) and unreacted kimberlite (controls 10 and 20) control bricks. (b) Comparing the compressive strength and 
stress-strain curves of bricks with the replacement of kimberlite carbonated at constant temperature $\left(35{ }^{\circ} \mathrm{C}\right)$, grouped by increasing moisture content $(1$ and $4=10 \% ; 2$ and $5=15 \% ; 3$ and $6=20 \%$ ) then by increasing $\mathrm{CO}_{2} \%(1,2$, and $3=10 \%, 4,5$, and $6=20 \%)$ on the seventh day of curing. (c) Comparing the compressive strength and stress-strain curves of bricks with replacement kimberlite carbonated at constant temperature $\left(35^{\circ} \mathrm{C}\right)$, grouped by increasing moisture content $(1$ and $4=10 \% ; 2$ and $5=15 \%$; 3 and $6=20 \%)$ then by increasing $\mathrm{CO}_{2} \%(1,2$, and $3=10 \%, 4,5$, and $6=20 \%)$ on the 28th day. (d) Comparing the compressive strength and stress-strain curves of bricks with replacement kimberlite carbonated at constant temperature $\left(50{ }^{\circ} \mathrm{C}\right)$, grouped by increasing moisture content $(7$ and $10=10 \%$; 8 and $11=15 \% ; 9$ and $12=20 \%$ ) then by increasing $\mathrm{CO}_{2} \%(7,8$, and $9=10 \%, 10,11$, and $12=20 \%)$ on the seventh day. (e) Comparing the compressive strength and stress-strain curves of bricks with replacement kimberlite carbonated at constant temperature $\left(50{ }^{\circ} \mathrm{C}\right)$, grouped by increasing moisture content $(7$ and $10=10 \% ; 8$ and $11=15 \% ; 9$ and $12=20 \%)$ then by increasing $\mathrm{CO}_{2} \%(7,8$, and $9=10 \%, 10$, 11 , and $12=20 \%$ ) on the $28^{\text {th }}$ day. (f) Comparing the compressive strength and stress-strain curves of bricks with replacement kimberlite carbonated at constant $\mathrm{CO}_{2} \%(10 \%)$, grouped by increasing moisture content $(1$ and $7=10 \% ; 2$ and $8=15 \% ; 3$ and $9=20 \%)$ and then by temperature $\left(1,2\right.$, and $3=35^{\circ} \mathrm{C} ; 7$, 8 , and $9=50{ }^{\circ} \mathrm{C}$ ) on the seventh day. (g) Comparing the compressive strength and stress-strain curves of bricks with replacement kimberlite carbonated at constant $\mathrm{CO}_{2} \%(10 \%)$, grouped by increasing moisture content $(1$ and $7=10 \% ; 2$ and $8=15 \% ; 3$ and $9=20 \%$ ) and then by temperature $(1,2$, and $3=35$ ${ }^{\circ} \mathrm{C} ; 7,8$, and $9=50{ }^{\circ} \mathrm{C}$ ) on the $28^{\text {th }}$ day. (h) Comparing the compressive strength and stress-strain curves of bricks with replacement kimberlite carbonated at constant $\mathrm{CO}_{2} \%(20 \%)$, grouped by increasing moisture content $(4$ and $10=10 \% ; 5$ and $11=15 \% ; 6$ and $12=20 \%$ ) and then by temperature $(4,5$, and $6=35{ }^{\circ} \mathrm{C} ; 10,11$, and $12=50{ }^{\circ} \mathrm{C}$ ) on the seventh day. (i) Comparing the compressive strength and stress-strain curves of bricks with replacement kimberlite carbonated at constant $\mathrm{CO}_{2} \%(20 \%)$, grouped by increasing moisture content ( 4 and $10=10 \% ; 5$ and $11=15 \% ; 6$ and $12=20 \%$ ) and then by temperature $\left(4,5\right.$, and $6=35^{\circ} \mathrm{C} ; 10,11$, and $\left.12=50{ }^{\circ} \mathrm{C}\right)$ on the 28th day. Bar graphs comparing the maximum compressive strength, and graphs comparing the stress-strain curves of bricks prepared without (a) and with (b-i) carbonated kimberlite replacement as a function of various carbonation parameters: temperature, moisture content, and $\mathrm{CO}_{2} \%$.

The control graph in Figure 8a shows that the bricks made from 10\% replacement (control 10) and $20 \%$ replacement (control 20) of cement by unreacted kimberlite had $-10 \%$ and $-30 \%$ reduced strength, respectively, when compared to the standard controls. Still, the stress-strain profiles of all controls remained similar, and followed the expected cracking/deforming/failure behavior, making these unreacted kimberlite bricks practically applicable as there will not be sudden failures of the bricks under loading. Still, it is clear that excessive replacement of unreacted kimberlite reduces the applicability of such bricks to a narrower range of service duties.

By comparing the graphs from Figure $8 \mathrm{~b}-\mathrm{i}$, it can be seen that, in general (with few deviations), the compressive strength of bricks cast with kimberlite carbonated at the highest $\mathrm{CO}_{2} \%(20 \%)$ and moisture content $(20 \%)$ reached higher values. These conditions are those that promote kimberlite thin-film carbonation, as higher $\mathrm{CO}_{2} \%$ accelerates mineral dissolution and subsequent carbonate precipitation, and higher moisture content maintains the solids adequately wet during thin-film carbonation. Hence, kimberlite that is better carbonated is seen to benefit the compressive strength of bricks that contain it as a partial replacement for cement. Amorphous silica $\left(\mathrm{SiO}_{2}\right)$ is a by-product of the carbonation of silicates, and this can contribute to strength gain during concrete curing. Additionally, small carbonate crystals can help fill and densify the concrete matrix.

By comparing the graphs from Figure $8 \mathrm{f}-\mathrm{i}$, the carbonation temperature effect can be more easily contrasted. The effect of carbonation temperature on compressive strength is not very clear, though there are more bricks prepared with kimberlite carbonated at higher temperature with greater compressive strength than bricks prepared with kimberlite carbonated at lower temperature. However, at lower carbonation moisture content, a higher temperature carbonation resulted, generally, in lower brick strength. This can be explained by the samples drying out more quickly at elevated temperature 
in thin-film carbonation, thus reducing the carbonation extent and making the mineral paste less evenly carbonated (pastes dry out first near the surface).

It is important to note that optimal thin-film carbonation conditions not only aim to maximize $\mathrm{CO}_{2}$ uptake of the mineral paste on average, but also aim to evenly carbonate the paste (from surface to depth), and the two are not necessarily conducted simultaneously. For example, bricks 3 and 10 had the worst strength performance, reaching the slowest maximum strengths and deforming sooner than the other bricks. Condition 3 used the highest moisture content with lowest $\mathrm{CO}_{2} \%$ and temperature, which can hinder $\mathrm{CO}_{2}$ transport to the mineral surface as a result of paste pore flooding. Condition 10, conversely, used the highest temperature and $\mathrm{CO}_{2} \%$ with the lowest moisture content, which can lead to the paste drying out more quickly. In both cases, uneven carbonation may be at fault, since in terms of furnace test results (Table 2), these samples are not too different than the others. It is interesting to note that these two conditions are at opposite ends of the process conditions envelope tested, which means that the other conditions are closer to optimal.

The compressive strength results, together with stress-strain curves, support the idea that alkaline earth metal oxides combine with $\mathrm{CO}_{2}$ to produce hard carbonates. Thus, the increase in strength in concrete prepared with carbonated kimberlite, rather than unreacted kimberlite, is directly related to the production of carbonates in the thin-film carbonated paste mix. These results show kimberlite's potential as a binder replacement for bricks, and can be expanded to other concrete components for better valorization. More tests should be done with various $\mathrm{CO}_{2} \%$, moisture contents and temperatures to optimize the $\mathrm{CO}_{2}$ uptake of the mineral paste and the subsequent strength gain of the concrete.

\section{Conclusions}

CCU by accelerated $\mathrm{CO}_{2}$ mineralization processes is a promising technology to combat greenhouse gas emissions by substituting traditional products with the long-scale storage of $\mathrm{CO}_{2}$. Though the amount of $\mathrm{CO}_{2}$ sequestered per tonne of carbonated kimberlite, under mild conditions, is comparatively low (up to $3.7 \mathrm{wt} \%$ as furnace test results showed), and the process demands energy, continuous research and innovation in the acceleration of mineral carbonation and process intensification can provide the breakthrough that it needs. From the result of compressive strength of the brick, very few samples were unsuitable due to deviated values. This may be due to uneven carbonation of kimberlite replaced in those bricks, but also due to improper compaction, mixing of the particles, surface finish, or orientation of the brick during testing. The optimum concrete mix is defined based on the strength that is demanded by the end user. The characteristic strength of cement bricks is expected to reduce with an increase in the use of kimberlite as a cement replacement beyond the values tested in this study, but carbonation was shown to improve the properties of kimberlite as a cement replacement.

In future research, the amount of $\mathrm{Mg}$ - and Ca-carbonates produced by $\mathrm{CO}_{2}$ sequestration in kimberlite through various accelerated and intensified mineral carbonation methods should be tested along with long-term studies to find the durability. Innovation in accelerated carbonation techniques is much needed for these studies. Focus on the physical properties such as kimberlite from various sources should be investigated to certify its binder characteristics by its composition. The mineralogy of the material, leaching properties, physical and mechanical properties like abrasion resistance, shape, specific gravity, bulk density, voids, and particle size distribution is much needed to understand its potential as aggregate and admixture. The effect of substituting kimberlite for cement on greenhouse gas emissions should be analyzed for further insight. Life cycle assessment (LCA) on the valorization process helps us to better understand the process energy demand and determine the feasibility of this process.

This study helps in reusing a material, reduces carbon footprint by storing the $\mathrm{CO}_{2}$ permanently in the material, reduces the usage of other resources, minimizes environmental impact, and valorizes mining waste by-product.

Author Contributions: Conceptualization, R.M.S.; Methodology, C.C. and R.M.S.; Investigation, C.C., S.C., and H.F.; Resources, R.M.S.; Writing—original draft preparation, C.C., S.C., and Y.E.C.; Writing-review and 
editing, Y.E.C., H.F., and R.M.S.; Supervision, R.M.S.; Project administration, R.M.S.; Funding acquisition, C.C., S.C., and R.M.S. All authors have read and agreed to the published version of the manuscript.

Funding: This research was funded by the Mitacs Globalink program, Barrett Family grant, and the Natural Sciences and Engineering Research Council of Canada (NSERC) Discovery Grant.

Acknowledgments: The authors thank the support of Mitacs for the Globalink research funding provided to C.C. and S.C.; the Natural Sciences and Engineering Research Council of Canada for the Discovery Grant research funding that supports the graduate bursaries of Y.E.C. and H.F.; the Barrett Family for the Barrett Grant research funding provided to support the acquisition of laboratory equipment used in this study; and De Beers Canada Inc. for providing the kimberlite tailings.

Conflicts of Interest: The authors declare no conflicts of interest.

\section{References}

1. Gibbs, M.J.; Soyka, P.; Conneely, D. Good Practice Guidance and Uncertainty Management in National Greenhouse Gas Inventories. 2001. Available online: https:/www.ipcc-nggip.iges.or.jp/public/gp/english/ (accessed on 4 June 2020).

2. Gavali, H.R.; Bras, A.; Faria, P.; Ralegaonkar, R.V. Development of sustainable alkali-activated bricks using industrial wastes. Constr. Build. Mater. 2019, 215, 180-191. [CrossRef]

3. Adiansyah, J.S.; Rosano, M.; Vink, S.; Keir, G. A framework for a sustainable approach to mine tailings management: Disposal strategies. J. Clean. Prod. 2015, 108, 1050-1062. [CrossRef]

4. Edraki, M.; Baumgartl, T.; Manlapig, E.; Bradshaw, D.; Franks, D.M.; Moran, C.J. Designing mine tailings for better environmental, social and economic outcomes: A review of alternative approaches. J. Clean. Prod. 2014, 84, 411-420. [CrossRef]

5. Poinot, T.; Laracy, M.E.; Aponte, C.; Jennings, H.M.; Ochsendorf, J.A.; Olivetti, E.A. Beneficial use of boiler ash in alkali-activated bricks. Resour. Conserv. Recycl. 2018, 128, 1-10. [CrossRef]

6. Zhang, L. Production of bricks from waste materials-A review. Constr. Build. Mater. 2013, 47, $643-655$. [CrossRef]

7. WBCSD. Cement Technology Roadmap 2009-Carbon Emissions Reductions up to 2050. 2009. Available online: http://www.cbcsd.org.cn/sjk/nengyuan/roadmap/20130516/download/Cement_Roadmap. pdf (accessed on 4 June 2020).

8. Balasubramanian, J.; Sabumon, P.C.; Lazar, J.U.; Ilangovan, R. Reuse of textile effluent treatment plant sludge in building materials. Waste Manag. 2006, 26, 22-28. [CrossRef] [PubMed]

9. Wolff, E.; Schwabe, W.K.; Conceição, S.V. Utilization of water treatment plant sludge in structural ceramics. J. Clean. Prod. 2015, 96, 282-289. [CrossRef]

10. Ukwatta, A.; Mohajerani, A. Characterisation of fired-clay bricks incorporating biosolids and the effect of heating rate on properties of bricks. Constr. Build. Mater. 2017, 142, 11-22. [CrossRef]

11. Rani, M.Y.; Bhagawan, D.; Himabindu, V.; Reddy, V.V.; Saritha, P. Preparation and characterization of green bricks using pharmaceutical industrial wastes. Environ. Sci. Pollut. Res. 2016, 23, 9323-9333. [CrossRef]

12. Goel, G.; Kalamdhad, A.S. An investigation on use of paper mill sludge in brick manufacturing. Constr. Build. Mater. 2017, 148, 334-343. [CrossRef]

13. Goel, G.; Kalamdhad, A.S. Degraded municipal solid waste as partial substitute for manufacturing fired bricks. Constr. Build. Mater. 2017, 155, 259-266. [CrossRef]

14. Demir, I. An investigation on the production of construction brick with processed waste tea. Build. Environ. 2006, 41, 1274-1278. [CrossRef]

15. Mekki, H.; Ammar, E.; Anderson, M.; Zina, M.B. The recycling of olive oil mill by-products in bricks. Ann. Chimie Sci. Materiaux 2003, 28, 109-127. [CrossRef]

16. Mekki, H.; Anderson, M.; Amar, E.; Skerratt, G.R.; Zina, M.B. Olive oil mill waste water as a replacement for fresh water in the manufacture of fired clay bricks. J. Chem. Technol. Biotechnol. 2006, 81, 1419-1425. [CrossRef]

17. Cotes Palomino, M.T.; Martínez García, C.; Iglesias Godino, F.J.; Eliche Quesada, D.; Corpas Iglesias, F.A. Study of the wet pomace as an additive in ceramic material. Desalin. Water Treat. 2016, 57, 2712-2718. [CrossRef]

18. José, A.; Lorite, M.; Jiménez, J.; Castro, E. Valorisation of wastewater from two-phase olive oil extraction in fired clay brick production. J. Hazard. Mater. 2009, 169, 271-278. 
19. Santos, R.M.; Van Bouwel, J.; Vandevelde, E.; Mertens, G.; Elsen, J.; Van Gerven, T. Accelerated mineral carbonation of stainless steel slags for $\mathrm{CO}_{2}$ storage and waste valorization: Effect of process parameters on geochemical properties. Int. J. Greenh. Gas Control. 2013, 17, 32-45. [CrossRef]

20. Baciocchi, R.; Costa, G.; Polettini, A.; Pomi, R. Influence of particle size on the carbonation of stainless steel slag for $\mathrm{CO}_{2}$ storage. Energy Procedia 2009, 1, 4859-4866. [CrossRef]

21. Bodénan, F.; Bourgeois, F.; Petiot, C.; Augé, T.; Bonfils, B.; Julcour-Lebigue, C.; Guyot, F.; Boukary, A.; Tremosa, J.; Lassin, A.; et al. Ex situ mineral carbonation for $\mathrm{CO}_{2}$ mitigation: Evaluation of mining waste resources, aqueous carbonation processability and life cycle assessment (Carmex project). Miner. Eng. 2014, 59, 52-63. [CrossRef]

22. Romanov, V.; Soong, Y.; Carney, C.; Rush, G.E.; Nielsen, B.; O'Connor, W. Mineralization of carbon dioxide: A literature review. ChemBioEng Rev. 2015, 2, 231-256. [CrossRef]

23. Ostovari, H.; Sternberg, A.; Bardow, A. Rock 'n' use of $\mathrm{CO}_{2}$ : Carbon footprint of carbon capture and utilization by mineralization. Sustain. Energy Fuels 2020. [CrossRef]

24. O'Connor, W.K.; Dahlin, D.C.; Rush, G.E.; Gerdemann, S.J.; Penner, L.R.; Nilsen, D.N. Aqueous Mineral Carbonation; Final Report DOE/ARC-TR-04-002; US Department of Energy: Albany, OR, USA, 2005.

25. Wang, X.; Maroto-Valer, M.M. Integration of $\mathrm{CO}_{2}$ capture and mineral carbonation by using recyclable ammonium salts. ChemSusChem 2011, 4, 1291-1300. [CrossRef]

26. Li, J.; Hitch, M. Mechanical activation of magnesium silicates for mineral carbonation, a review. Miner. Eng. 2018, 128, 69-83.

27. Ghoorah, M.; Dlugogorski, B.Z.; Balucan, R.D.; Kennedy, E.M. Selection of acid for weak acid processing of wollastonite for mineralisation of $\mathrm{CO}_{2}$. Fuel 2014, 122, 277-286. [CrossRef]

28. Mervine, E.M.; Wilson, S.A.; Power, I.M.; Dipple, G.M.; Turvey, C.C.; Hamilton, J.L.; Vanderzee, S.; Raudsepp, M.; Southam, C.; Matter, J.M.; et al. Potential for offsetting diamond mine carbon emissions through mineral carbonation of processed kimberlite: An assessment of De Beers mine sites in South Africa and Canada. Mineral. Petrol. 2018, 112, S755-S765. [CrossRef]

29. Bodor, M.; Santos, R.M.; Kriskova, L.; Elsen, J.; Vlad, M.; Van Gerven, T. Susceptibility of mineral phases of steel slags towards carbonation: Mineralogical, morphological and chemical assessment. Eur. J. Mineral. 2013, 25, 533-549. [CrossRef]

30. Bukowski, J.M.; Berger, R.L. Reactivity and strength development of $\mathrm{CO}_{2}$ activated non-hydraulic calcium silicates. Cem. Concr. Res. 1979, 9, 57-68. [CrossRef]

31. Van der Plas, G.; Limaye, P.; Loi, I.; Mercha, A.; Oprins, H.; Torregiani, C.; Thijs, S.; Linten, D.; Stucchi, M.; Katti, G.; et al. Design issues and considerations for low-cost 3-D TSV IC technology. IEEE J. Solid-State Circuits 2010, 46, 293-307. [CrossRef]

32. Santos, R.M.; Van Gerven, T. Process intensification routes for mineral carbonation. Greenh. Gases Sci. Technol. 2010, 1, 287-293. [CrossRef]

33. ASTM International. ASTM: C67-14, Standard Test Methods for Sampling and Testing Brick and Structural Clay Tile; ASTM: West Conshohocken, PA, USA, 2014.

34. Morgan, B.; Wilson, S.A.; Madsen, I.C.; Gozukara, Y.M.; Habsuda, J. Increased thermal stability of nesquehonite $\left(\mathrm{MgCO}_{3} \cdot 3 \mathrm{H}_{2} \mathrm{O}\right)$ in the presence of humidity and $\mathrm{CO}_{2}$ : Implications for low-temperature $\mathrm{CO}_{2}$ storage. Int. J. Greenh. Gas Control. 2015, 39, 366-376. [CrossRef]

35. Zhang, Z.; Zheng, Y.; Ni, Y.; Liu, Z.; Chen, J.; Liang, X. Temperature-and pH-dependent morphology and FT-IR analysis of magnesium carbonate hydrates. J. Phys. Chem. B 2006, 110, 12969-12973. [CrossRef]

36. Power, I.M.; Wilson, S.A.; Harrison, A.L.; Dipple, G.M.; Mccutcheon, J.; Southam, G.; Kenward, P.A. A depositional model for hydromagnesite-magnesite playas near Atlin, British Columbia, Canada. Sedimentology 2014, 61, 1701-1733. [CrossRef]

37. Hwang, K.-Y.; Kim, J.Y.; Phan, H.Q.H.; Ahn, J.-Y.; Kim, T.Y.; Hwang, I. Effect of $\mathrm{CO}_{2}$ concentration on strength development and carbonation of a MgO-based binder for treating fine sediment. Environ. Sci. Pollut. Res. 2018, 25, 22552-22560. [CrossRef] [PubMed]

38. Obe, R.K.D.; De Brito, J.; Mangabhai, R.; Lye, C.Q. Sustainable Construction Materials: Copper Slag; Woodhead Publishing: Cambridge, UK, 2016. [CrossRef]

39. ASTM International. ASTM: C618-19, Standard Specification for Coal Fly Ash and Raw or Calcined Natural Pozzolan for Use in Concrete; ASTM: West Conshohocken, PA, USA, 2012. 
40. Salman, M.; Cizer, Ö.; Pontikes, Y.; Santos, R.M.; Snellings, R.; Vandewalle, L.; Blanpain, B. Van Balen, K. Effect of accelerated carbonation on AOD stainless steel slag for its valorisation as a $\mathrm{CO}_{2}$-sequestering construction material. Chem. Eng. J. 2014, 246, 39-52. [CrossRef]

41. Canadian Concrete Mansory Producers Association. Physical Properties, Metric Technical Manual. 2020. Available online: https://ccmpa.ca/wp-content/uploads/2012/02/Final2013Sec4.pdf (accessed on 23 June 2013).

42. Kuranchie, F.A.; Shukla, S.K.; Habibi, D. Utilisation of iron ore mine tailings for the production of geopolymer bricks. Int. J. Min. Reclam. Environ. 2016, 30, 92-114. [CrossRef]

(C) 2020 by the authors. Licensee MDPI, Basel, Switzerland. This article is an open access article distributed under the terms and conditions of the Creative Commons Attribution (CC BY) license (http://creativecommons.org/licenses/by/4.0/). 